\title{
Political Stability as a Main Factor for Simplicity, Neutrality and Stability of Trade
}

\author{
Giga Abuseridze \\ Rìga Stradiṇš University, \\ Doctoral Study Programme Legal Science, Georgia \\ giga.abuseridze@yahoo.com
}

\begin{abstract}
In the given article, the author names main factors of the trade norms: simplicity, stability and neutrality and reveals the empirical model, factors that contribute to trade norms simplicity stability and neutrality. To begin with the explanation of political behaviour, it is notable that theories of political behaviour attempt to quantify and explain the influences that define a person's political views, ideology, and levels of political participation.

Keywords: International Monetary Fund (IMF), European Union, World Trade Organization.

\section{Introduction}

Political behaviour can be met everywhere. For example, members of society behave politically while they are obeying or disobeying the laws of society, and supporting or undermining the power stratification system [2]. Political behaviour takes place in organised society. People in interaction behave in the context of shared expectations about what can be done in any given situation, according to the law. For these people, the variability of behaviour patterns is limited. So, such behaviour can be predicted, to some extent. The stated above allows for the following conclusion: to say that people are in interaction as opposed to random contact is to say that they act out roles, to some degree.

Political stability can be defined as the regularity of the flow of political exchanges. Political behaviour or act, or exchange is regular if it does not violate the system (or pattern) of political exchanges, whereas its irregularity is expressed through the violation of that pattern. The network of political roles in a given society forms the society's political structure. If one thinks of political roles in terms of their function in controlling
\end{abstract}


the flow of transactions and communications among political actors, one may refer to political structure as the system of political exchanges.

If political stability is understood as the regularity of the flow of political exchanges, then it must be accepted that the more regular the flow of political exchanges, the more stable they should be. It is necessary to point out that regular exchanges do not violate the laws of the society, while irregular exchanges do. It should not be assumed that it is always clear whether or not a form of behaviour violates the law. Such an assumption is unnecessary. Rather, it may be considered necessary to regard a possible violation of the law as an issue if it is resolved by appeal at the court or at an institution which the society uses for compulsory arbitration. The main reason for using law and custom as the arbiters of role expectations is that the two constitute the system of sanctions which gives political structure its particular character [2].

There are several perspectives on political stability, and all of them will be discussed in greater detail in this scientific work. For instance, according to Helliwell's argument about the indirect effect of democracy on the economic growth, there is an indirect effect of democracy on growth through the channel of political stability. Taylor and Hudson proposed the three varieties of instability mentioned earlier, namely, "irregular government change", "major regular government change" and "minor regular government change" [3]. Meanwhile, regular and irregular government changes are also supposed to have different impacts on economic growth.

\section{Political Stability from the Perspective of Economical Politics}

The International Monetary Fund's conditions for its loans create problems of political stability for developing countries. The Fund's conditions are seen as rather harsh measures, which are likely to lead to economic austerity, which in turn will provoke political instability. Some observers single out the Fund's role as having special implications for political stability because of the way that the Fund mandates adjustments to balance of payments difficulties, because it is an outside institution, and because it is sometimes perceived to be an ally of industrial country banks and governments with its own conservative political agenda [5].

The IMF, however, provides resources that make adjustment easier and thus may lessen the chances of instability. Further, IMF policies, it may be argued, are more likely to generate economic success and avoid the political instability associated with economic chaos.

Most commentators on IMF programmes are not very specific about the political and economic interactions that, they believe, produce political instability. They do not weigh the alternatives to IMF conditionality and continued access to the IMF's resources nor have been precise about defining the political instability that is presumed to follow from IMF conditionality. Before proceeding to analyse the characteristics of 
IMF programmes, therefore, it is necessary to define political instability and highlight two important determinants of instability, namely, elite unity and legitimacy. Some examples will be provided in the context of IMF conditionality. "Instability" commonly refers both to a process and to an outcome. Change is the outcome, and the process is thought to be one accompanied by violence and unpredictability. "Change" itself is often modified to mean rapid alterations. All analysts of instability should, but do not always, specify whether they are referring to changes of incumbents who run governments-heads of state, central bankers, finance ministers-or of values, roles, and institutions. Rulers may change while leaving intact governing ideologies or political and economic systems [6].

\section{Economic Factors Contributing to Political Stability}

Political stability based on the sound economic development of its Member States is regarded to be the main goal of the European Union [6]. The EU appears to be an ideal arena for an experiment in how organisations facilitate cooperation across diverse, self-interested, and competing rational actors. When nation-states accede to regional organisations, they aim to extract particular political and economic benefits through regional cooperation with their neighbours. However, in order to support their own aims of extracting benefits from a regional organisation, it is essential to secure collective support for the mechanisms that enable regional organisations to effectively create the desired conditions. At the minimal level, regional organisations should be governed by the established norms and rules underlying the interactions between nation-states, in order to enhance predictability, trust, and cooperation.

According to Heyneman, when regional organisations wish to govern the relations between the governments of nation-states, they influence regional cooperation through "the acceptance of institutional rules that pertain across organisations within the same category of purpose" [20]. This enables cooperation through the adherence to accepted institutional rules that engender trust among national actors, and regional organisations thereby have the ability to effectively contribute to social cohesion in a region. In turn, a region marked by high levels of social cohesion both within and across member states is likely to experience better developmental possibilities that accompany political stability and sound economic relationships with neighbours.

Political stability is largely influenced by a number of economic factors: unemployment, the level of tax (Fiscal Policy), growth in incomes, inflation.

\section{Unemployment}

High unemployment threatens social stability in any nation. In fragile countries, which are too weakened by violent conflict to guarantee citizens the rule of law, security and welfare, unemployment aggravates all other problems [19]. The proportion of individuals who have continuously been unemployed for a long period of time 
(12 months and longer) attracts particular attention from labour market policy makers and researchers in all countries and political blocks, including the EU. Recent research has shown that gender, age, marital status, region, previous work experience and, to lesser extent, education are the main predictors of long-term unemployment [4]. The issue of political stability becomes even more problematic in countries with high unemployment rate where a large number of young people are unemployed.

European countries, in particular, have long been discussing the need to reform and reduce government's labour market regulation. However, while rationale for government intervention in the labour market is linked to the need to correct market imperfections, it is still not clear why government regulation in the labour market is so pervasive and why reforms are so difficult to implement. In particular, these authors argue that because labour market policies require time to be designed and implemented, weak and unstable government (i.e. the one without the political power to sustain the reform process and unsure to be in office in the next period) will find it optimal to limit policy discretion of future governments by regulating the labour market. They have developed a model in which government intervention in the labour market (i.e. its policy stance) is linked to the structure of the political process and its stability (i.e. ability to be re-elected), and in this model political instability is the main driver of government labour market policy stance. Importantly, these authors have proven that in countries where the political process is less stable and more fragmented, there is a stronger government intervention in the labour market and unemployment is, on average, higher [16].

Unemployment has always been at the centre of the socio-economic policy in the $\mathrm{EU}$ because it is one of the most disturbing problems hindering the labour market and the macroeconomic performance and the individual well-being, which altogether influences the level of political stability in the region. It is obvious that an increasing level of unemployment aggravates inequality, poverty and crime issues that always undermine political stability [14]. According to Eurostat, in July 2011, Euro area unemployment rate was estimated $10.0 \%$, while unemployment rate in all $27 \mathrm{EU}$ Member States reached $9.5 \%$ [9]. However, Lagana highlights that, alongside the risk of unemployment, the EU labour market is highly susceptible to the entrapment of its increasingly mobile workforce in unskilled occupations [15]. In addition, recent research findings show that the penalisation of immigrants is lower in countries where the quality of labour demand is poorer, unemployment benefits are less generous, the employment protection legislation is stricter and the proportion of refugees is lower [10].

Therefore, taking into consideration that EU immigrants come from various countries (both inside and outside the Union), it is essential to provide for better incorporation of immigrants in the EU labour market because political stability in the region requires that the level of unemployment be moderate. 
Giga Abuseridze. Political Stability as a Main Factor for Simplicity,

Neutrality and Stability of Trade

\section{The Level of Tax (Fiscal Policy)}

The use of discretionary fiscal policy as a counter-cyclical tool has declined in popularity over the last 30 years [22]. Both a small calibrated model and a larger econometric model suggest that the intertemporal consumer should smooth away most of the impact of temporary tax changes, even when additional discounting and credit constraints are allowed. However, this analysis suggests a more powerful role for other forms of fiscal policy, such as government objections to the use of discretionary fiscal stabilisation policy, as well as makes a tentative suggestion as to how these might be overcome.

A fiscal policy refers to the choice of tax rates, and of the level and composition of government spending, whereas a tax reform relates to the broad design of a tax system that determines the available tax bases and the technology for collecting taxes [8]. A tax reform that changes the tax system will, typically take time and resources, since it requires investment in the acquisition of information and in infrastructure. Meanwhile, a fiscal policy, on the other hand, can be implemented more swiftly [18]. Thus, at any given moment in time, the existing tax system acts as a constraint on the fiscal policy of the current government. This suggests that tax reforms should also be determined by strategic considerations: a tax system is designed by taking into account how it will constrain the fiscal policies of future governments [13].

Tax reforms are also determined by strategic considerations: a tax system is designed by taking into account how it will constrain the fiscal policies of future governments. The central idea of this section is that, if there is political instability and political polarisation, these strategic considerations may induce the current government to leave an inefficient tax system to its successors. The author suggests that the interdependence of a fiscal policy and of the level of political stability could be expressed by the following assumption: the higher the level of tax - the lower the interest of investors - the higher unemployment - the higher political unrest among society - the lower political stability.

\section{Growth in Incomes}

To begin with, it is worth mentioning that the question of the effect of income and the income distribution on the political system is complicated by the two-way character of the causal path. This the so-called "path" connects income with politics. If, for example, there is great inequality of income in a democracy, the median voter will have an increased incentive to support heavily progressive taxes. It will be so since the opportunities for redistribution from the wealthy to the non-wealthy will be great. The more equal the distribution of income is, the less the median voter will have to gain from such taxes because the less income the wealthy will have to be taxed away. There is some evidence, that income is more equal in democratic than in non-democratic nations (where "democracy" is defined not just formally, but in terms of actual behaviour such as voter turnout) as a result of the political system. 
Giga Abuseridze. Political Stability as a Main Factor for Simplicity,

Neutrality and Stability of Trade

It should be admitted that successful democracies are widely held to be liberal states [17]. It is so because pure, direct, plebiscitary democracy, democracy with no legal or institutional checks on majority rule, is bound to unravelling into dictatorship. For instance, John Stuart Mill considered the modem welfare state to be more democratic and less liberal, in other words, optimal. Such a kind of state typically allows for considerable occupational freedom and almost completes personal freedom. It also implies recognition and protection of property rights, although less than laissez-faire liberals would like. The net effect of these liberties on the income distribution cannot be predicted but they certainly complicate democratic efforts to bring about equality of income through taxation and other forced measures.

According to Kuznets, economic development involves a shift of labour from a traditional agricultural sector to a modern industrial sector. Higher productivity in the modern sector allows employers to attract workers from the traditional sector by offering higher wages. A less equal distribution of income is likely to be the result of such short-sighted actions on the part of employers. Inequality will decline and more effective redistribution of income from rich to poor will take place after the low-wage traditional sector shrinks and democratic institutions are founded. In this case, domestic political instability will display the following features [7]:

1) domestic political instability will be the main cause of international terrorism because terrorism is more likely to stem from politically unstable countries. Severe political instability (for example, civil wars) allows terrorists to acquire specific skills that would be difficult to acquire under less drastic forms of domestic political instability (such as anti-government demonstrations);

2) after 1989, domestic political instability tends not to decrease over time;

3) finally, the severity of terror attacks is likely to increase over time even if the number of attacks does not change.

It has to be pointed out that political stability largely depends on economic aspects. Therefore, trade is an important indicator for both political and economic stability. When trade decreases, it does not only imply that there is a lack of production but also shows that there is a lack of political stability. Trade can also be seen as an indicator of how effectively a state deals with its neighbours [11].

The effects of political instability on economic growth are measured with variables which have been established in the theoretical literature mentioned in this paper. Among those are ethnic and religious diversities in countries. A society which is separated into ethnic or religious groups is unsteady, and this imbalance and instability is often caused by both ethnic and religious discrepancies. However, taking into account the long-term co-existence of different ethnic groups in European states, it can be stated that Western Europe manages to provide for political stability regardless of the ethnic and religious diversity of its population, which, yet, can be attributed to the relatively high economic development of Western European countries. 
Giga Abuseridze. Political Stability as a Main Factor for Simplicity,

Neutrality and Stability of Trade

\section{Inflation}

Based on the results of their analysis of the interrelationship of inflation and political stability, Aisen and Veiga prove that political instability leads to higher inflation, while higher degrees of economic freedom and democracy are associated with lower inflation [1]. It has been established that institutions such as economic freedom and democracy are important determinants of inflation. In addition, it has been proven that the impact of political instability on inflation is much stronger for high-inflation than for moderate- and low-inflation countries, and it is also higher for developing countries than for industrial countries.

Indeed, political stability and economic stability, achieved by strict control over inflation, have always reinforced each other. High inflation can have deep undesired social and political consequences. In fact, severe inflation can be more disruptive than a recession because it literally destroys people's earnings and savings, which, in turn, can result in drastic political dramas (e.g. coups, suspension of democracy or overthrow of power). That is why central banks undertake any possible measures to suppress hyperinflation: political stability in a region can be ensured only if economic processes follow positive scenarios.

\section{Conclusion}

As it can be seen, economic growth, based on moderate level of unemployment, adequate fiscal policy, controlled inflation and increasing growth of incomes, is one of the most important conditions that facilitate political stability. It has to be added that, in accordance with the neoclassical growth model, the growth rate tends to be negatively related to the absolute level of per capita GDP, owing to diminishing returns to capital. Numerous empirical findings have found support for this argument. In this study, the real GDP per capita in 1960 is used as an indicator of initial economic development, which is expected to have a negative effect on growth. Yet, it is also human capital accumulation that is regarded as another important factor for economic growth by some scholars.

Political stability as a result of social processes and economic developments, showing how closely related these aspects are in providing political stability of Trade, indicate that all these perspectives on political stability are very important for the sustenance of democracy and healthy economic development in the EU or WTO because irregular political changes, such as coups d'etat, instil great amounts of uncertainty into the market-place, tend to slow down and even reverse economic growth in a given region and this often deteriorates the well-being of society, which in turn may increase political instability in the region. 
Giga Abuseridze. Political Stability as a Main Factor for Simplicity,

Neutrality and Stability of Trade

\section{Politiskā stabilitāte kā galvenais tirdzniecības vienkāršības, neitralitātes un stabilitātes faktors}

\section{Kopsavilkums}

Raksta autors nosauc tirdzniecības normu galvenos faktorus - vienkāršību, stabilitāti un neitralitāti - un atklāj empīrisko modeli, faktorus, kas tos veicina. Lai paskaidrotu politisko darbību, ir jāatzīmē, ka politiskās uzvedības teorijas mēǵina noteikt un izskaidrot, kas nosaka kādas personas politiskos uzskatus, ideologiju un politiskās līdzdalības līmeni.

Atslēgvārdi: Starptautiskais Valūtas fonds, Eiropas Savienība, Pasaules Tirdzniecības organizācija.

\section{References}

1. Aisen, A., Veiga, F. J. Does political instability lead to higher inflation? A panel data analysis. IMF Working Paper 05/49, March 2005, 3.

2. Ake, C. A definition of political stability. Comparative Politics. 1975, 7 (2), 271.

3. Alesina, A. et al. Political instability and economic growth. NBER Working Paper No. 4173, 1992, 1-7.

4. Alhawarin, I., Kreishan, F. An analysis of long-term unemployment (LTU) in Jordan's labor market. European Journal of Social Sciences. 2010, 15 (1), 56.

5. Bienen, H. S., Gersovitz, M. Economic stabilization, conditionality, and political stability. International Organization. 1985, 39 (4), 745.

6. Bienen, H. Violence and Social Change. University of Chicago Press, 1986, 109.

7. Campos, N. Gassebner, M. The roots of terrorism: Economic development, political instability and the escalation effect, 2011, pp. 6-7. Iegūts no: http://www.naurocampos.net/escfeb2011.pdf

8. Cukierman, A. Central Bank Strategy, Credibility, and Independence. Theory and Evidence. Massachusetts Institute of Technology, 1998, 60.

9. Eurostat (2011), July 2011. Euro area unemployment rate at $10 \%$ EU27 at $9.5 \%$. No: Eurostat. Iegüts no: http://europa.eu/rapid/pressReleasesActiondo?reference=STAT/11/124\&formatHTML\&aged $=0$ \&language $=$ EN\&guiLanguage $=$ en

10. Fullin, G., Unemployment trap or high job turnover? Ethnic penalties and labour market transitions in Italy. International Journal of Comparative Sociology. 2011, 52 (4), 285.

11. Goldsmith, A. Does political stability hinder economic development? Mancur Olson's Theory and the third world. Comparative Politics. 1987, 19 (4), 477.

12. Heyneman, P., Brent, P. Stability for development, development for stability: The relationship between regional organizations and social cohesion through the lens of the EU and MERCOSUR. Peabody Journal of Education. 2011, 86, 130.

13. Hinrichs, H. A General Theory of Tax Structure Change during Economic Development. Harvard University Law School, 1996, 163.

14. Hooghe et al. Unemployment, Inequality, Poverty and Crime: Spatial Distribution Patterns of Criminal Acts in Belgium, 2001-2006. British Journal of Criminology, 51, 2011, p. 1. 
Giga Abuseridze. Political Stability as a Main Factor for Simplicity,

Neutrality and Stability of Trade

15. Lagana F. Blocked mobility or unemployment risk? Labour market transitions of natives and immigrants in Switzerland. International Journal of Comparative Sociology. 2011, 52 (4), 327.

16. Lucifora, C., Moriconi, S. Political instability, labour market regulation and unemployment, November 2008, pp. 1-2. Iegūts no: http://www.eale.nl/Conference2009/Programme/PapersF/ add102588_26Pw14kWvW.pdf

17. Posner, R. Equality, wealth, and political stability. Journal of Law, Economics, and Organization. 1997, 344-365.

18. Rogers, A. Changing Tax Bases in a Model of Endogenous Tax Reforms. Georgetown University, 1989, 120.

19. Schultze, A. Work brings security, 2011. Iegūts no: http://www.inwent.org/ez/articles/171940/ index.en.shtml

20. Solow, R. A contribution to the theory of economic growth. The Quarterly Journal of Economics. 1956, 70 (1), 68.

21. Trostel, P. Micro evidence on human capital as the engine of growth, 2000. Iegūts no: http:// wrap.warwick.ac.uk/1622/1/WRAP_Trostel_twerp555.pdf

22. Wren-Lewis, S., The limits to discretionary fiscal stabilization policy. Oxford Review of Economic Policy. 2000, 16 (4), 93-94.

23. Zakaria, F. The secrets of stability. Newsweek, 12/21/2009, 154, (25), 54. 